Columbia Law School

Scholarship Archive

2020

\title{
The Covid-19 Pandemic and Business Law: A Series of Posts from the Oxford Business Law Blog
}

\author{
Gert-Jan Boon \\ Leiden University Law School, j.m.g.j.boon@law.leidenuniv.nl \\ Markus K. Brunnermeier \\ Princeton University, markus@princeton.edu \\ Horst Eidenmueller \\ University of Oxford, horst.eidenmueller@law.ox.ac.uk \\ Luca Enriques \\ University of Oxford, luca.enriques@law.ox.ac.uk \\ Aurelio Gurrea-Martínez \\ Singapore Management University School of Law, aureliogm@smu.edu.sg
}

See next page for additional authors

Follow this and additional works at: https://scholarship.law.columbia.edu/faculty_scholarship

Part of the Banking and Finance Law Commons, Bankruptcy Law Commons, and the Business

Organizations Law Commons

\section{Recommended Citation}

Gert-Jan Boon, Markus K. Brunnermeier, Horst Eidenmueller, Luca Enriques, Aurelio Gurrea-Martínez, Kathryn Judge, Jean-Pierre Landau, Marco Pagano, Ricardo Reis \& Kristin van Zwieten, The Covid-19 Pandemic and Business Law: A Series of Posts from the Oxford Business Law Blog, OXFORD LEGAL STUDIES ResearCh PAPER No. 15/2020 (2020).

Available at: https://scholarship.law.columbia.edu/faculty_scholarship/2640

This Working Paper is brought to you for free and open access by the Faculty Publications at Scholarship Archive. It has been accepted for inclusion in Faculty Scholarship by an authorized administrator of Scholarship Archive. For more information, please contact scholarshiparchive@law.columbia.edu. 


\section{Authors}

Gert-Jan Boon, Markus K. Brunnermeier, Horst Eidenmueller, Luca Enriques, Aurelio Gurrea-Martínez, Kathryn Judge, Jean-Pierre Landau, Marco Pagano, Ricardo Reis, and Kristin van Zwieten 


\title{
The COVID-19 Pandemic and Business Law: A Series of Posts from the Oxford Business Law Blog
}

\author{
GERT-JAN BOON \\ MARKUS BRUNNERMEIER \\ HORST EIDENMÜLLER \\ LUCA ENRIQUES \\ AURELIO GURREA-MARTÍNEZ \\ KATHRYN JUDGE \\ JEAN-PIERRE LANDAU \\ MARCO PAGANO \\ RICARDO REIS \\ KRISTIN VAN ZWIETEN
}

The full text of this paper can be downloaded without charge from the

Social Science Research Network electronic library at:

https://ssrn.com/abstract=3573419 


\title{
The COVID-19 Pandemic and Business Law:
}

\section{A Series of Posts from the Oxford Business Law Blog}

\author{
GERT-JAN BOON • MARKUS BRUNNERMEIER • HORST EIDENMÜLLER \\ LUCA ENRIQUES • AURELIO GURREA-MARTÍNEZ • KATHRYN JUDGE \\ JEAN-PIERRE LANDAU • MARCO PAGANO • RICARDO REIS \\ KRISTIN VAN ZWIETEN
}

\begin{abstract}
The COVID-19 Pandemic is the biggest challenge for the world since World War Two, warned UN Secretary General, António Guterres, on 1 April 2020. Millions of lives may be lost. The threat to our livelihoods is extreme as well. Job losses worldwide may exceed 25 million.

Legal systems are under extreme stress too. Contracts are disrupted, judicial services suspended, and insolvency procedures tested. Quarantine regulations threaten constitutional liberties. However, laws can also be a powerful tool to contain the effects of the pandemic on our lives and reduce its economic fallout. To achieve this goal, rules designed for normal times might need to be adapted to 'crisis-mode', at least temporarily. Business Laws in particular fulfil an important function in this context. Our livelihoods depend on how well businesses are able to navigate through the current crisis.

Beginning in early February 2020, the Oxford Business Law Blog has published posts on how Business Laws could contribute to containing the effects of the COVID-19 Pandemic, and on how they need (or need not) to be adapted to achieve the desired effect. This working paper collects the posts published throughout March in chronological order. ${ }^{1}$ Thematically, the focus is on finance, financial regulation and insolvency laws. This is not surprising as the most pressing problem businesses face right now is to manage their cash flow. We hope that the contributions in this paper inspire more work by scholars and help policymakers worldwide to adopt the right measures to reduce the damage caused by the Pandemic.
\end{abstract}

\footnotetext{
1 The Oxford Business Law Blog has, in addition, published the following posts, summarizing working papers available on SSRN and therefore not included here: Syren Johnstone, Blockhain, AI and the Wuhan Coronavirus (5 Febr. 2020), Graham Steele, Avoiding the 'Climate Lehman Moment' (12 Mar. 2020), and Mimi Zou, Virtual Justice in the Time of COVID-19 (16 Mar. 2020)
}

2 The COVID-19 Pandemic and Business Law: A Series of Posts from the Oxford Business Law Blog 


\section{Table of Contents}

1. Stock Exchange Shutdowns in the Time of Coronavirus, Luca Enriques............... 4

2. Should We Ban Short Sales in a Stock Market Crash?, Marco Pagano .................... 7

3. Throwing a COVID-19 Liquidity Life-Line, Markus Brunnermeier, Jean-Pierre

Landau, Ricardo Reis \& Marco Pagano ............................................................................. 10

4. COVID-19: A Global Moratorium for Corporate Bonds?, Kristin van Zwieten,

Horst Eidenmüller \& Luca Enriques .................................................................................. 13

5. Directors' Duties of Financially Distressed Companies in the Time of COVID-

19, Aurelio Gurrea-Martínez ................................................................................................. 16

6. Enhancing Private Donations in the Fight Against COVID-19, Luca Enriques .. 19

7. The Wrong Target? COVID-19 and the Wrongful Trading Rule, Kristin van Zwieten

8. Congress Should Endorse the Federal Reserve's Extraordinary Measures, Kathryn Judge 24

9. COVID-19 Crisis Requires Legislators to Adapt Insolvency Legislation, Gert-Jan Boon 27

10. The Race to Fight COVID-19: On the Desirability of Regulatory Competition, Horst Eidenmüller 


\section{Stock Exchange Shutdowns in the Time of Coronavirus}

\section{LUCA ENRIQUES}

If stocks were still traded in pits, stock exchanges would have been shut down in China, Korea, Italy and possibly elsewhere a while ago. A bunch of men shouting and feverishly passing each other sheets of papers would have spread coronavirus faster than the now infamous Korean sect.

But stock exchange trading was automated everywhere long ago, including at the Borsa Italiana in Milan. Nowadays, the only virus that can be transmitted by trading shares is panic selling. Is that an even better reason for shutting down stock markets, as some high-profile Italians politicians, including former Prime Minister Matteo Renzi, suggested last Sunday?

It is reassuring that the Italian Government ignored the suggestion and even more reassuring that in a statement on Sunday the Italian securities regulator, Consob, appealed to reasonableness by reminding everyone that ' $\mathrm{t}$ ] he trading halt of all stock market negotiations ... would be a decision that would switch off the price indicator without removing the causes, generating market problems that are not easy to solve in the immediate future'. In other words: a stock exchange shutdown is the financial equivalent of getting rid of the thermometer when it signals fever: the only outcome is that it becomes more difficult to understand how serious the flu is and how it is evolving.

And there is more: a stock exchange shutdown means putting more pressure on other financial instruments whose prices are correlated to that of Italian shares. Think of an investor who holds both Italian equity and Italian Treasury bonds in their portfolio. Given the greater impact of coronavirus in Italy than elsewhere, they might want to reduce their exposure to the country. If they were not allowed to sell the equity, to compensate for that they would sell more Treasury bonds, thereby contributing to the rise in their interest rate. Should Italy then also ban Treasury bond trading? Treasury bonds are traded outside Italy as well. A shutdown limited to domestic trading venues would only drain the bonds' liquidity and hence make it much more onerous for the state to issue new bonds (something the Italian state does every few weeks). It would thus lead to the Government (hence, Italian taxpayers) having to pay higher interest rates in attempting to stopping downward speculative pressures on the equity market. To put it another way, attempting to curb the losses of 
the minority of Italian citizens who are invested in shares ${ }^{2}$ would be at the expense of taxpayers generally.

Additionally, the result of shutting down the stock exchange is to make the savings of those who are invested in it unavailable at a time of emergency, which is exactly when savers/investors may need to convert them into cash. This would be true not only for those who have bought shares directly, but also for those who have done so via mutual funds: how can an asset manager accept withdrawal requests if it can't sell the assets in the fund's portfolio and it is impossible to determine their value? In all likelihood, the asset manager would make use of its power, according to the contract with the unitholders, to suspend withdrawals until the stock exchange reopens.

Finally, the most intractable problem with shutting down exchanges is the fact that sooner or later they have to be reopened. In the present circumstances, for how long should the Italian stock exchange be closed? The problem being coronavirus, a few days would make no difference. Should they stay closed until the 3rd of April, like Italian schools? Does that sound too early? At the time of post-Lehman temporary bans on short selling (2008-09), Consob's commissioners were periodically convened to decide whether to extend them. They repeatedly renewed them, in the fear that, otherwise, Consob would be held politically liable should downward speculative pressures resume. The dynamics would be the same today. It would be difficult for Consob, should positive developments in the fight against the virus and in economic conditions not materialise soon enough (as everyone hopes), to decide that trading should resume.

Hence, the shutdown could go on for weeks and weeks. If you suppress investors' liquidity needs for so many days, the downward pressure once the stock exchange reopens will be even stronger. Worse, once it becomes clear that the Italian stock exchange may shut down for weeks in the case of an emergency, investors, both Italian and offshore, would have to factor in that new illiquidity risk, which will make it less attractive to hold Italian shares and will therefore require investors to rebalance their portfolios: again, when the market reopens, this additional reason for selling would increase the downward pressure on prices. In addition to the temporary liquidity shock, the demand for Italian shares would go down for the longer term as well, raising Italian firms' cost of capital.

In truth, however, at least in Europe all of this is financial regulation fiction: as Consob's statement clarified, the regulator lacks the power to shut down the entire stock exchange. Even a shutdown through an emergency law by the Government

\footnotetext{
2 The Italian pension system is pay-as-you-go and Italian pension funds' exposure to equity (globally) is negligible, as annual reports of the Italian pension funds regulator show.
} 
would be unlikely to apply to trading activity on non-Italian trading venues, where Italian shares could well continue trading: an extraterritorial ban would likely be against EU rules, impossible to enforce, or both. The only effect of such an emergency law would thus be of reducing, but not halting, trading. That would have a strong negative impact on liquidity, would increase volatility, and raise the cost of executing transactions. The symptoms of panic selling would still be visible and the lower trading volumes would even amplify them. To conclude, a stock exchange shutdown would be a remedy worse than the disease.

Luca Enriques is Professor of Corporate Law at the University of Oxford. Between 2007 and 2012 he was a Commissioner at Consob.

This post was published on 12 March 2020. It is the translation of an op-ed published in the Italian daily il Foglio and available (behind paywall) here. 


\title{
Should We Ban Short Sales in a Stock Market Crash?
}

\author{
MARCO PAGANO
}

Few things are more predictable than loud demands for regulatory interventions to 'stop speculation' when stock market prices plunge: in these days, as in any recent stock market crash, we hear politicians and commentators inviting regulators to enact interventions spanning from stock trading suspension to a short sales ban. In the past, stock market regulators typically bowed to such demands: banning short sales is almost their 'Pavlovian response' when faced with widespread drop in stock market prices.

Over the last twenty years, unfortunately there has been no shortage of crises, so that we have had the opportunity to observe this 'Pavlovian response' of regulators repeatedly and in many countries. On September 19, 2008, immediately after the Lehman collapse shook investors' confidence in the soundness of banks and brought down the prices of their shares, the Securities and Exchange Commission (SEC) banned short selling of shares in banks and financial companies in the US. This ban was quickly imitated by the majority of other countries: some only banned 'naked short sales', in which the seller does not borrow shares to deliver them to the buyer during the settlement period; others also banned covered short sales, in which the seller protects himself by borrowing the shares. More recently, during the sovereign debt crisis of 2011-12, regulators in most eurozone countries have reacted in the same way to share prices drops, especially those in the banking sector.

These hasty interventions, while varying from country to country in intensity, scope and duration, were invariably presented as aimed at restoring the orderly functioning of the markets and avoiding unwarranted drops in stock prices, and their destabilizing effects. For example, in 2008 the SEC justified its intervention with these words: 'unbridled short selling is contributing to the recent sudden price declines in the securities of financial institutions unrelated to true price valuation'. In the UK, the Financial Services Authority motivated the short-selling ban it introduced on 18 September 2008 for financial stocks as follows: 'sharp share price declines in individual banks were likely to lead to pressure on their funding and thus create a self-fulfilling loop'. Similarly, in 2012 the Spanish stock market regulator (CNMV) explained its decision to retain the ban introduced in 2011 arguing that 'failure to ban short sales would heighten uncertainty', and that accordingly keeping the ban was 'absolutely necessary to ensure the stability of the Spanish financial system and 
capital markets'. In short, the conditioned reflex of the regulator rests on this argument: in times of crisis, stock prices fall below their 'true valuation', which can destabilize banks and therefore the financial system; by prohibiting short selling, we prevent too pessimistic investors from 'expressing their opinions' on the market regarding the value of the shares, hence we avoid the destabilizing undervaluation that would follow.

While apparently sensible, this argument has serious flaws, both in principle and in fact. First, the argument assumes that regulators know better than the market what the 'true valuation' of securities is, better than the thousands of investors who spend huge resources every day to also try to calculate such true valuations, so as to buy undervalued securities and sell overvalued ones. But if so, why don't the authorities that oversee security markets intervene even when prices rise above 'true valuations', before the market crashes? If we ban short sales to prevent unwarranted price drops, we should symmetrically ban 'excessive' purchases leading to unwarranted security market booms!

Second, the empirical evidence that has accumulated over the years, especially in the last two decades, shows that the ban on short selling is neither able to support security prices, nor to make banks more stable. In a study published with Alessandro Beber in the Journal of Finance in 2013, we analyzed daily data on 16,491 shares in 30 countries between January 2008 and June 2009. Our results indicate that the shortselling bans implemented over those months did not go hand in hand with increases or lower drops in the prices of exchange, except in the United States in the two weeks following the application of the ban, an exception probably due to the simultaneous announcement of bank bailouts by the United States government. In other countries, where the bans were not accompanied by announcements of bank bailouts, or also targeted non-bank shares, or did not target bank shares at all, the ban on short selling does not seem to have supported security prices. The estimates indicate that banning naked short sales did not have significant effects on share prices, and banning covered short sales even made them decrease! A subsequent work carried out with Alessandro Beber, Daniela Fabbri and Saverio Simonelli in 2018 also shows that, contrary to what expected by regulators, banks whose securities were subject to short-selling bans even featured an increased probability of insolvency, compared to other banks featuring similar risk and size but exempt from the ban.

Third, the empirical analysis shows that short-selling bans have significant negative 'side effects'. They tend to considerably reduce the liquidity of the markets, because they are accompanied by an increase in bid-ask spreads, especially for smaller companies: reducing market liquidity is particularly damaging in crisis conditions, when liquidity is already in short supply and investors seek it desperately. Furthermore, these bans substantially reduce the information efficiency of security 
markets, that is, the speed with which new information is impounded in prices: trying to 'silence the pessimists' makes everyone less informed and thus increases market uncertainty!

The conclusion suggested by the evidence is therefore well summarized by the words pronounced on 31 December 2008 by the former president of the SEC, Christopher Cox: 'Knowing what we know now, I believe on balance the commission would not do it again. The costs (of the short-selling ban on financials) appear to outweigh the benefits.' Hopefully, supervisors around the world will remember this lesson now that they are facing a new financial crisis.

Marco Pagano is Full Professor of Finance at the University of Naples Federico II and Director, Centre for Studies in Economics and Finance.

This post was published on 13 March 2020. It is the translation of an op-ed published in the Italian daily il Foglio and available (behind paywall) here. 


\title{
Throwing a COVID-19 Liquidity Life-Line
}

\author{
MARKUS BRUNNERMEIER \\ JEAN-PIERRE LANDAU \\ RICARDO REIS \\ MARCO PAGANO
}

Effective economic policies are urgently required to deal with the enormous strain that the global epidemic is putting on all of the European Union (EU) economies. Right away, a key dimension in which the EU can help is in overcoming the liquidity shortages for firms that are facing a temporary yet dramatic drop in their revenues. This is essential if they are to keep on:

a) Paying wages to their employees. Firing them would cause great suffering for some that are unable to meet basic needs, trigger a drop in household consumption, and lead to defaults on fixed commitments, such as rents or school fees. It would require new re-matching of workers and jobs in the near future, a costly and slow process that would lead to great losses in productivity and prolonged unemployment.

b) Repaying their other debt obligations. These include both trade credit from suppliers and short-term loans from banks and other financial institutions. Without them, default would cascade through firms and economic sectors and across borders. Banks would fail and financial systems would be in turmoil for many years to follow.

Providing the necessary liquidity could be done with a Euro-wide scheme that provides direct funding on a large scale and with urgency-ideally, in a few weeks. We envision a scheme in which the European Investment Bank (EIB) borrows from the European Central Bank (ECB), and extends loans at a favourable interest rate to firms strapped for cash. The national tax authorities would then over a period of a few years collect the revenues to recover the loan and pay back the EIB. Specifically, we envisage the following steps:

1. The EIB grants (senior) loans to all firms solely for the purpose of covering payments due in the next few months, say the next semester. Loans are granted against documentation that a debt payment was due. They can be extended directly to firms, or indirectly by the firms instructing the banks and other creditors to collect payment from the EIB. These loans are granted at 
0\% interest and are to be paid back in the form of an annuity over the next few (say, 8) years. In principle, the EIB can channel the loans via the national fiscal authorities.

2. The loans are repaid by entrusting the recovery of their instalments to the national tax authorities, as an add-on to the tax liabilities of the respective firms. This drastically reduces the collection costs of the EIB, because tax authorities have a superior technology to enforce repayment. Moreover, because tax liabilities are typically the most senior claims in bankruptcy, this reduces credit risk.

3. The EIB funds these loans by placing (investment-grade) bonds with the ECB, which provides the necessary liquidity. The ECB is free to manage its portfolio afterwards, including selling these bonds in the market to private investors if it wishes to. Going through the EIB avoids having the ECB do the allocation of funds across member states, which is politically sensitive.

Why not channel these loans via banks? This scheme greatly helps the banks, since it allows firms to repay in full their debts on current outstanding loans. Hence, it will reduce non-performing loans and help stabilize banks. At the same time, the direct nature of the funding scheme avoids intermediation by banks. This guarantees that the money will flow directly to firms in all the EU member states, irrespective of the health and efficiency of national banking systems. Moreover, since the crisis in the short run is hitting firms and their payments directly, rather than banks, it makes sense to target the funding scheme to firms directly. Of course, banks, consumers, and all others economic agents will benefit from preventing the widespread failure of firms.

Why do this at the European rather than at the national level? There are good economic and political reasons to do so:

- The overarching economic rationale is that the health shock is common to all, and if some countries don't respond adequately, the cascading of defaults and drop in consumption would affect all. Some countries can provide this liquidity with national funds, while others cannot, but all will suffer if some fail to do it. Moreover, in times of great stress for financial markets, involving the EIB and the ECB is required: in the Euro area the ECB is the only liquidity provider, so that any Europe-wide liquidity injection, especially on the scale envisaged here, must rest on its full involvement.

- Politically, citizens across Europe are wondering whether at times of need they can count on the EU as their 'common home'. If the EU will not to rise to 
this challenge, and only national solutions are offered, many citizens will question the European project and drift to nationalist parties.

Markus Brunnermeier is the Edwards S. Sanford Professor of Economics at Princeton University.

Lean-Pierre Landau is Associate Professor of Economics at SciencesPo (Paris).

Ricardo Reis is the A.W. Phillips Professor of Economics at the London School of Economics.

Marco Pagano is Full Professor of Finance at the University of Naples Federico II and Director, Centre for Studies in Economics and Finance.

This post was published on 18 March 2020. 


\title{
COVID-19: A Global Moratorium for Corporate Bonds?
}

\author{
KRISTIN VAN ZWIETEN \\ HORST EIDENMÜLLER \\ LUCA ENRIQUES
}

The alarming prospect of widespread defaults by economically viable firms has prompted various proposals for assistance from states. Access to new finance can be facilitated by the state guaranteeing draw-downs on bank overdraft/lines of credit facilities, emergency loans, or, in the case of larger firms, by state purchases of commercial paper. However, firms might face financial distress before these measures become effective. Smaller firms with concentrated capital structures may well be able to informally negotiate an extension of maturity with their lenders, provided those lenders (typically banks) are given speedy and sufficient assistance from the state to enable them to make value-maximising accommodations to debtors. But debtors with fragmented capital structures may not be able to arrange workouts so easily. In this piece, we suggest a novel form of relief for corporates whose capital structures have been fragmented by bond issues.

Our proposal is this: that emergency legislation be introduced to extend the maturity of bond debt. The basic idea would be to 'buy time' for large corporates, reducing the risk of fire sales. In the UK context, we envisage primary legislation providing that, notwithstanding anything to the contrary in bond contracts, English law governed bond debt cannot fall due for payment within, say, 180 days of entry into force of the legislation. Acceleration clauses would have no effect in this period, nor would debtors be required to create a sinking fund or post (additional) collateral. However, debt due to mature after 180 days would be unaffected. Debtors who could pay would not be prevented from paying. However, a saving provision might need to be included to avoid penalties for early payment where debt contracts provide for this. Equivalent legislation could be introduced elsewhere to deal with debt governed by the law of other jurisdictions, including New York law in particular.

An obvious objection to our proposal is that most jurisdictions already have a formal mechanism for shielding debtors from enforcement action by creditors in times of crisis. Nudged by international development banks, most jurisdictions have one or more procedures in which debtors can obtain a stay with a view to negotiating a restructuring with creditors, the law typically providing that, where a court agrees, a minority can be bound to the will of a similarly situated majority. Where there is a 
ready market for the purchase of the business, such a renegotiation with creditors should be unnecessary (Baird 1986); where there is not, however (for example, because the debtor's distress is shared by others in the same industry: Shleifer and Vishny 1992), such procedures can provide a route to value preservation by providing tools to overcome the coordination problems associated with renegotiation.

Given the availability of reorganisation procedures with statutory moratoria, why do we propose that the UK Parliament intervenes to directly lengthen the maturity of English law governed bond debt? Our primary reason is that conventional reorganisation procedures cannot be trusted to deliver value-maximising outcomes for a large number of debtors in multiple sectors of the real economy who become financially distressed simultaneously. Reorganisation procedures are complex to administer and, almost by definition (because their characteristic feature is the ability to bind dissenters to a change in rights) court-intensive. The experience of other large-scale corporate crises suggests that bankruptcy courts can quickly become overburdened (see e.g. Stone 2002 or Cirmizi, Klapper and Uttamchandani 2010). This seems a particularly acute risk in the current crisis, given that COVID-19 is also straining courts in other ways: physical court closures are highly likely, and any virtual equivalents will take time to be established. Most importantly, courtsupervised insolvency procedures are associated with significant direct and indirect costs, causing a potentially fatal loss in value of the financially distressed firm. In this context, non-court based solutions should be prioritised. Hence our focus on statutory intervention at the contractual level.

Clearly, our proposal is only sensible if it can reasonably be expected that the courts of other jurisdictions would treat the debt contracts as validly altered by the statute, for a great deal of English law governed debt has been issued by corporates with assets (and even centres of main interests) abroad. Would foreign courts resist this on the basis that doing so would be manifestly contrary to the public policy of their state? The obvious concern would be that the statutory amendment amounts to an impermissible interference with property rights (protected under international human rights law) but for the reasons set out immediately below we think that the interference is fully justified. As such, we are optimistic about the efficacy of our proposed intervention abroad.

We acknowledge that a modification of contractual rights is likely to be characterised as an interference with property rights for the purposes of Article 1 of Protocol 1 of the European Convention on Human Rights. However, there must surely be a powerful case that this time-limited measure (which would preserve bondholder rights other than in respect of the length of maturity) is fully justified in the 'public interest', as permitted by Article 1 of Protocol 1, given the extraordinary economic imperative for the measure. Concerns about proportionality could additionally be met 
by providing for sectors to be carved out from the scope of the intervention in subsequent regulations, which might be valuable for those (few) sectors that do not need it (such as groceries distributors or medical equipment producers).

We recognise that our proposal may not be sufficient to avoid unnecessary filings: if directors are subject to a mandatory filing rule, this would also need to be relaxed. This possibility is already being explored elsewhere, as charted by Aurelio Gurrea Martinez in a forthcoming post. English law does not impose a mandatory filing rule on directors. Instead, directors run the risk of personal liability if they know or ought reasonably to know that it is inevitable that the debtor will end up in balance sheet insolvent liquidation or administration, and they fail from that point in time to take every step with a view to minimising potential loss to creditors that they ought to have taken (ss214/246ZB of the Insolvency Act 1986). Our proposal would indirectly, and we suggest beneficially, affect the operation of this provision by giving directors greater comfort that the unnecessary opening of insolvency proceedings can be avoided. To put it another way, insolvency proceedings may no longer be an inevitability with our proposed extension in maturity. If even with the benefit of this intervention (and the other battery of interventions from the state) directors still know (or ought to know) that insolvency proceedings are inevitable, then under the current law they will have to take every relevant step. But English courts will only ask what it would have been reasonable for the particular director to do; the courts must resist invitations to use hindsight; and they can only order compensation be paid where the failure to take appropriate steps is causally linked to loss suffered by the company (see e.g. Grant v Ralls).

We recognise that our proposal will mean that some businesses that should have deleveraged already will be given more time than they otherwise should have been given. But for the reasons we have set out we do not think that now is the right time to require courts to supervise reorganisations, and doubt that (at least for most industries) there will be ready markets for going concern sales. The ex ante effects of being overly generous to these debtors should be limited, given the highly exceptional nature of the crisis.

Kristin van Zwieten is Clifford Chance Associate Professor of Law and Finance at the University of Oxford

Horst Eidenmüller is Freshfields Professor of Commercial Law at the University of Oxford.

Luca Enriques is Professor of Corporate Law at the University of Oxford.

This post was published on 23 March 2020. 


\title{
Directors' Duties of Financially Distressed Companies in the Time of COVID-19
}

\author{
AURELIO GURREA-MARTÍNEZ
}

Unlike other jurisdictions around the world, several European countries require corporate directors to file for bankruptcy once a company becomes insolvent. For instance, under German law, corporate directors are required to file for bankruptcy within three weeks since they know, or ought to have known, that the company became insolvent on a balance-sheet or a cash-flow basis. Failure to comply with this duty may expose the directors to both civil and criminal liability. In Spain, a similar duty is imposed. However, instead of exposing directors to criminal liability, they can be subject to other sanctions (including disqualification and liability for the company's debts) and the bankruptcy petition has to take place within two months rather than three weeks. Such a duty can be extended, however, for four additional months if the directors notify the court the commencement of negotiations with the company's creditors with the purpose of reaching an out-of-court agreement.

In addition, regardless of whether a company is insolvent, many European countries also impose certain duties on corporate directors when, as a result of the existence of losses, the company's net assets fall below a certain percentage of the company's legal capital. For example, under Spanish corporate law, directors are required to promote the dissolution, restructuring or bankruptcy of the company within two months since they know-or ought to have known-that the company's net assets have fallen below $50 \%$ of the company's legal capital. If they fail to do so, directors will be liable for the company's new debts.

Due to the impact of the coronavirus in Europe, many companies will be exposed to both losses (as a result of their fixed costs and decline in revenues) and insolvency (due to many companies' inability to generate the cash-flows needed to meet their financial obligations). For this reason, I recently wrote an article advocating for a legal reform in Spain that can nevertheless be applied to other countries. Among other policy recommendations, I suggested that the legislator should suspend both the duty to file for bankruptcy and the duty to promote the dissolution or restructuring of those companies whose net assets fall below $50 \%$ of the company's legal capital. In the absence of these measures, which should last long enough to let companies overcome the financial difficulties generated by the COVID19 , many otherwise viable companies would be forced into liquidation or bankruptcy 
proceedings. Therefore, the legal framework would exacerbate the harmful economic effects already created by the coronavirus.

During the past days, it seems that some European countries have decided to take actions on these matters. On 16 March 2020, the German Government announced a suspension on the duty to file for bankruptcy for companies affected by the coronavirus. One day later, the Spanish Government implemented a reform in the same direction (see articles 40.11, 40.12 and 43 of the Royal Decree $\underline{8 / 2020}$ of 17 March 2020).

However, the Spanish approach differs from both my policy recommendations and the German approach in various relevant aspects. First, instead of imposing a suspension lasting long enough to let Spanish companies recover from the losses and financial difficulties generated by the coronavirus, as it was suggested in my article and has been announced by Germany (that is planning to suspend the duty to file for bankruptcy until 30 September 2020, with the possibility of an additional extension to 31 March 2021), the Spanish suspension will just apply while the country remains in a state of emergency (estado de alarma), which has been declared until 29 March 2020, even though it can extended by Parliament.

Second, with the purpose of avoiding the opportunistic use of this suspension, my proposal just targeted companies or economic sectors affected by the coronavirus, which seems to be the solution likely to be adopted in Germany. In Spain, however, the suspension targets all companies.

Third, while Germany has merely suspended the duty to file for bankruptcy (due to the absence of a 'recapitalize or liquidate' rule, as it exists in Spain as well as in Italy, France and Sweden), Spain has suspended both the duty to file for bankruptcy (applicable to insolvent firms) and the duty to promote the dissolution, bankruptcy or restructuring of the company (applicable to companies whose net assets fall below $50 \%$ of the company's legal capital). In my opinion, this latter legal response was necessary in Spain- aas well as in other countries with a recapitalize or liquidate rule in place. Otherwise, solvent and viable companies just reporting losses might be forced to exit the market. Yet, the Spanish response can be criticized for having erred in the design of the suspension: on the one hand, its scope is too broad. On the other, its temporal extension is too limited.

Fourth, unlike the solution that has been announced in Germany, Spain has also suspended creditors' right to file an involuntary bankruptcy petition. In this regard, the Spanish response seems very reasonable. Otherwise, even if the suspension of the duty to file for bankruptcy shields corporate directors from liability for a failure to file for bankruptcy in a timely manner, the company can still be put into bankruptcy. And if so, apart from having to bear the direct and indirect costs associated with a 
procedure that, in the absence of these exceptional circumstances, would not even be needed, the directors may be removed from the company's management and, particularly in Spain, they can still be subject to several sanctions, including disqualification and special liability rules.

While these reforms will not help improve the financial situation of the companies affected by the coronavirus, and therefore need to be accompanied by other economic, financial, labor, legal and tax measures (some of which have already been implemented), they still represent a significant improvement. On the one hand, they provide companies and directors with a breathing space. On the other hand, these reforms help avoid the destruction of value associated with liquidating economically viable firms just facing financial trouble due to a totally exogenous factor such as the coronavirus. Therefore, these corporate and insolvency law responses deserve to be applauded. In fact, they may even serve as a model for other countries heavily affected by the coronavirus, even if, under those jurisdictions, the duties of corporate directors in situations of insolvency and/or qualified losses are not as rigid as those existing in Germany and Spain. Besides, by having learnt from the flaws and limitations associated with the Spanish and, to a lesser extent, the German solutions, other countries could implement a more comprehensive response to effectively address the challenges of applying normal-times corporate and insolvency laws in the midst of a once-in-a-century global pandemic.

Aurelio Gurrea-Martínez is an Assistant Professor of Law at Singapore Management University.

This post was published on 24 March 2020. 


\section{Enhancing Private Donations in the Fight Against COVID-19}

\section{LUCA ENRIQUES}

In recent weeks, crowdfunding campaigns for donations to hospitals, $\underline{\text { n }}$ Italy and elsewhere, have dramatically multiplied. Amplified by social media postings, such campaigns make it extremely easy for everyone to contribute with a small or a large sum to cope with the covid-19 emergency, reducing (one hopes) the risk of a collapse of national health services. In Italy, for example, top fashion influencer Chiara Ferragni and her husband have raised more than $4 \mathrm{~m}$ euro to build a new intensive care unit at a hospital in Milan in less than two weeks through a Gofundme campaign.

The problem with such campaigns, meritorious though they of course are, is that there is no way for the donor to know which hospital or geographic area is most in need of their donation. Of course, intuitively where the number of infections is higher, there is more use for additional funds, but that's a pretty crude metric: a given area with a high number of infections may have a much better network of hospitals than another with a lower number of infections and may be less in need of additional cash than the latter. Hence, one's social media feeds risk being much more decisive in the allocation of vital private funds than if there were no information asymmetry as to where funds are most needed.

China's solution has been unsurprisingly top-down and centralized, as Syren ఏohnstone has reported in this Blog: 'Beijing has ordered all public donations for the Wuhan crisis to be funnelled to five government-backed charity organisations,' which carries the risk of funds mishandling, as Johnstone also reminds us based on past experience with the same solution. Western democracies may, however, prefer tools that are more in line with commitments to individual freedom and decentralised decision-making, if not with people's greater distrust in the government.

One way forward would be for governments to collaborate with donation crowdfunding portals such as GoFundMe and JustGiving. These portals could aggregate all crowdfunding campaigns in a single page in favor of hospitals and other units of the NHS (one example of this strategy already exists in Italy: see here). The Government, for its part, could use the data on the disease and its trends to create a summary indicator of the needs of individual hospitals, cities and counties, provinces or states. For example, an algorithm could predict, area by area and hospital by hospital, the difference between the free beds in intensive care units and the 
foreseeable number of patients in the following ten to fifteen days, the gap between masks available and the amount needed not to endanger the health of nurses, doctors and hospital patients, and so on: possibly, the data available at the central level will not be so granular, but surely Governments already have verified information to evaluate where the funding gaps are greatest: using the appropriate models, those data could be easily converted into a single funding-gap score to facilitate comparisons.

When used by donation crowdfunding portals, this objective, reasonably reliable and ideally regularly updated score would allow potential donors to make better choices about the hospital or the area to which to donate. (Because the data fed into it would be the same the government already uses to allocate scarce public funds orders of magnitude greater than prospective donation flows, the increase in the risk of cheating on the part of potential recipients should be low and one can assume that governments already have systems in place to verify the data.) For example, donors could choose from week to week whether to send funds to their area of residence or to the hospital closest to their parents' home, depending on where the emergency is greater from time to time.

The advantages of this mechanism are obvious. First of all, it would not replace but complement and reinforce all current mechanisms, including the campaigns of social media influencers: influencers themselves could choose their beneficiaries more effectively. Second, individuals' incentives to donate would be reinforced, as they would know that they are helping where help is most needed. Nor would there necessarily be the risk of an excess of resources in the direction of a given hospital, provided the score was updated daily, having regard to the progress of existing fundraising campaigns.

Private donations are of course not a complete solution to the Covid-19 health care emergency. But a more efficient allocation of this exceptional form of funding is in everyone's interest, and it would also give greater satisfaction to the many who in these days are providing excellent proof of their generosity.

This post is an adapted translation of an op-ed published in the Italian daily il Foglio and available (behind paywall) here.

Luca Enriques is Professor of Corporate Law at the University of Oxford.

This post was published on 25 March 2020. 


\title{
The Wrong Target? COVID-19 and the Wrongful Trading Rule
}

\author{
KRISTIN VAN ZWIETEN
}

Governments around the world are urgently considering how to support businesses in the COVID-19 crisis. In the UK context, one proposal is for the UK Parliament to temporarily suspend the operation of the wrongful trading rule in the Insolvency Act 1986 (see, eg, here). In this short post, I suggest that the effects of a such a suspension would in technical terms be very limited, but that this does not mean that the proposal is necessarily a bad one.

The wrongful trading rule appears in ss.214 and 246ZB of the Insolvency Act 1986. The former provides the rule for companies in (insolvent) liquidation; the latter for companies in administration. These are the two collective insolvency procedures provided by English law. 'Wrongful trading' is a misnomer: the rules are not concerned only with trading decisions, and they contain no prescription or proscription in relation to such decisions. Instead, the rules provide more generally that a director who knows or ought to know that there is no reasonable prospect of avoiding the commencement of balance-sheet insolvent liquidation or administration is liable to be ordered to make a contribution to the company's assets (in the event that the company ends up in those proceedings and the action is brought by the liquidator or administrator) unless they can establish that, from that point in time on, they took every step with a view to minimising potential loss to creditors that they ought to have taken. The standard is an objective one but can be raised by reference to the knowledge, skill and experience of the director in question.

The rationale for the proposed relaxation in the rules is presumably to avoid directors 'shutting up shop' too early, and in particular to avoid the unnecessary commencement of insolvency proceedings for debtors that become financially distressed in the COVID-19 crisis but whose underlying business is sound. Directors who do not have to fear personal liability for 'wrongful trading', it might be thought, may feel freer to 'wait out' the crisis, and this might be thought desirable if it seems unlikely that value will be maximised in formal insolvency proceedings. Such proceedings are very costly even in good times; in a time of pan-industry crisis, when courts are at risk of being overwhelmed and markets for going concern sales are likely limited, there seems a particular imperative to avoid unnecessarily filings (on this, see an earlier post by Professors Enriques, Eidenmueller and myself, here). 
The problem with this analysis is that the wrongful trading rule is not the only source of personal liability for the directors of insolvent companies under English law. Instead, it is one of a number of rules which overlap with each other. These include the so-called 'common law' rule in West Mercia Safetywear $v$ Dodd, and the compensation order provisions of the Company Directors Disqualification Act 1986 which were added to that Act in 2015.

The effect of the rule in West Mercia is that the ordinary duties owed by directors to the company are altered when the company is insolvent or is likely to become insolvent ( BTI 2004 LLC V Sequana SA) so as to require directors to have enhanced regard for the interests of creditors. This duty shift affects all of directors' duties, both of loyalty and of care. It is complemented by a restraint on shareholder authorisation or ratification, such that shareholders cannot cure a breach of creditor-regarding duty.

It seems to me that all of the behaviour that is regulated by s.214 is also perfectly capable of being regulated by directors' duties, as those duties are affected by the rule in West Mercia Safetywear $v$ Dodd; indeed, there are some forms of behaviour that are regulated more effectively by the West Mercia rule than s.214, which is rather restrictive when it comes to remedies (see van Zwieten 2018). The main difference between relying on s.214 and relying on West Mercia is that the former is an office-holder action, the fruits of which enure for the general body of unsecured creditors, while the latter is an action brought in the company's name, such that the fruits are susceptible to capture by a secured creditor who has taken security over all the assets of the company, present and future.

The compensation order regime in the CDDA 1986 has only just begun to be applied in the courts, but on a plain reading it is clear that there is potential for substantial overlap between the compensation order regime on the one hand, and the wrongful trading and West Mercia rules on the other. But because the new rules have some novel features (including a focus on compensating for loss caused to creditors, rather than loss caused to the company), they may also result in directors being made subject to compensation orders in circumstances where no remedy would have been recoverable under either the wrongful trading rule or under the law governing directors' duties as affected by the rule in West Mercia (see van Zwieten 2020, expressing concern about this).

The upshot is that it is doubtful whether suspending the wrongful trading rule will actually limit in any meaningful way the scope of directors' personal liability under English law. The main effect in technical terms seems to me that where an action could previously have been brought either under s.214 or under the rule in West Mercia, only the latter will be available, with the result that secured creditors 
may benefit in a way they would not have benefited if the action had been brought under s.214. This potential cost to unsecured creditors must of course be balanced against the expected benefits of the suspension, and there does seem to me to be one such benefit: a public announcement of the suspension of a 'wrongful trading rule' might signal to directors of insolvent companies that a decision to attempt to continue to trade, in one form or another, is not per se unlawful. That has never been the law, but signalling this to directors who are currently 'under siege' and who might therefore be at particular risk of being misled by the misnomer ('wrongful trading') could still be helpful.

Should lawmakers go further, and relax the other rules I have identified? I am not convinced that the rule in West Mercia should be relaxed. It is true that rules of this kind might deter honest entrepreneurs from taking risks even where likely to be value maximising. That is a cost of duty-shifting rules ( $\mathrm{Hu}$ and Westbrook 2007), and perhaps this cost is greater in the context of a crisis like the present one, where directors will already be feeling generally risk-shy. Against this, however, must be balanced the need to facilitate the extension of new credit to already distressed businesses, and (relatedly) to facilitate workouts in relation to existing indebtedness. The Government is rightly focused on encouraging and enabling creditors to do this, but they may well be less inclined to cooperate if the signal sent by lawmakers is that the ordinary rule, by which creditors are positioned as the constituency that directors must serve when the debtor is insolvent, does not apply. I doubt that support will be forthcoming if creditors cannot be assured that their interests will be treated as paramount if and for so long as the debtor is actually insolvent, and this is what West Mercia provides. I am far less enthusiastic about the compensation order regime, which seems to me to be far too wide, but suspect there will be little appetite for reviewing this flagship reform anytime soon.

Kristin van Zwieten is Clifford Chance Associate Professor of Law and Finance at the University of Oxford.

This post was published on 25 March 2020. 


\title{
Congress Should Endorse the Federal Reserve's Extraordinary Measures
}

\author{
KATHRYN JUDGE
}

The rapid spread of Covid-19 and massive change in behavior required to curb it have transformed the trajectory of the world's economy. Just a few short weeks ago, the United States was basking in the longest period of sustained economic growth on record. The country now faces what could be the steepest decline in economic activity in its history. The long-term health of the country and the economy remain fluid and will be determined in part by how policymakers respond. The Federal Reserve quickly recognized the unprecedented nature of the threat and has intervened aggressively to stem the pain this crisis will inflict on the long-term health of the real economy. Congress should now authorize the Fed's most creative interventions and give the Fed explicit, albeit time limited, authority to go even further.

The Fed has been at the forefront of the government's efforts to soften the tremendous economic blow of Covid-19. There is no way to avoid much of the suffering to come. Public health officials are rightfully driving policy and behavior. Their message is clear: To reduce the human suffering from Covid-19, we need to flatten the curve. That means spending a lot more time at home and virtually none in shared spaces. That means empty restaurants, empty factories, empty classrooms, empty hotels, empty offices... and only a fraction of that activity can shift to the virtual worlds everyone is now being asked to inhabit. Although this may be necessary for public health, the economic consequences are devastating.

The Fed was quick to respond. Consistent with its mandate to promote full employment and its obligations to promote systemic stability, the Fed pulled out every known tool. It rapidly slashed interest rates to near zero. It ramped up the dollar liquidity swap lines relied on heavily during the 2008 financial crisis to funnel dollars to and through central banks around the world. It reinstated many of the special credit facilities it had used to stem the 2008 financial crisis, including one to support money market mutual funds and another to funnel liquidity to primary dealers, and it provided a broad list of eligible collateral. It has also gone on a buying spree, and-in an unprecedented move-committed to effectively unlimited quantitative easing, meaning it will buy up as many Treasuries and government agency mortgage-backed securities as it needs to in order to keep those markets functioning well. 
But there's more. The Fed has also implemented two programs to effectively buy up corporate debt, including secondary debt already trading and new issuances that it stands ready to buy directly from large, creditworthy corporations. It also announced its intention to launch a new Main Street Business Lending Program to encourage lending to small and midsized companies. And, as important as any of the individual programs, the Fed signaled a willingness to continue to act creatively and aggressively to address the growing threats. The press release to announce the new set of programs opened: 'The Federal Reserve is committed to using its full range of tools to support households, businesses, and the US economy overall in this challenging time.'

The Federal Reserve has not been acting unilaterally. The expanded credit facilities have all been created under Section 13(3) of the Federal Reserve Act, which allows the Fed, in 'unusual and exigent circumstances' to extend collateralized loans to nonbanks, just as it normally provides to banks via the discount window. After questions about the Fed's use of that authority during the 2008 crisis, Congress modified Section 13(3) to require the US Treasury secretary, in addition to five members of the Federal Reserve Board, to approve any facility. The Treasury Department has further agreed to fund an equity stake in the special entity vehicles through which a number of the new facilities will be run. Although not statutorily required, this signals the Treasury's willingness to share in the losses given the credit risk that these programs may entail.

The blessing of the administration conveyed through the Treasury Department's actions is important. The Fed's most recent interventions could expose the Fed to meaningful credit risk. Technically, it is extending collateralized loans, not buying risky assets. But the way the Fed makes these interventions look like loans is by creating new entities that will do nothing but buy up qualifying assets, such as corporate debt, that the Fed is not authorized to buy. With the exception of the very narrow slice of equity being provided by the Treasury Department, these newly created entities will be funded entirely by the Fed, which means the Fed also bears the downside risk if those loans aren't paid in accordance with their terms. Looking ahead, that possibility cannot be discounted even for creditworthy firms. The mix of interventions also has important allocational effects, which is why decisions about the types of assets that can be used as collateral have been followed so closely. The two new debt facilities, for example, inevitably confer a disproportionate benefit on large, otherwise healthy companies, as they are the only companies positioned to issue the investment grade debt that the Fed has authorized the new programs to acquire.

None of this means that these programs are inappropriate. Exceptional times call for exceptional measures. Moreover, the Fed's ability to use special purpose vehicles to creatively deploy its authority under Section 13(3) was on full display during the last 
crisis and was something Congress understood well when it modified other aspects of Section 13(3) in the Dodd-Frank Act.

The issue at stake is not just the lawfulness of the Fed's actions, but also how best to preserve the long-term independence of the Federal Reserve. The Fed also acted creatively and aggressively in 2008. Those actions likely helped make the recession that followed less searing than it would otherwise have been. Nonetheless, as the dust settled and the ramifications became clearer, politicians from both sides of the aisle went after the Fed. There was a movement afoot not only to scale back its emergency-era authority, but to also scale back its independence with respect to monetary policy or even to do away with the Fed entirely. Although the Fed survived and retained its independence, the threat was real and would have cost the country dearly.

The same thing could happen again. No one yet knows how the Covid-19 pandemic will play out, and the Fed has little control over its evolution. Depending on how bad things get and how long the bad times last, a lot of companies and other borrowers may not be able to pay their debts when due, no matter how healthy they were before this calamity hit. A public that is mired in a wave of unemployment and foreclosures may not take kindly to seeing just how much money the Fed injected into certain parts of the economy, regardless of the systemic rationale underlying those actions.

Issues of accountability also come into play. At the broadest levels, the balance of powers scheme built into the US Constitution gives Congress the power of the purse. Although the reality has long deviated from that ideal, the ideal remains important. Congress is made up of elected officials from all 50 states. Those officials both reflect the views of their constituents when making law and act as mouthpieces for new laws, explaining to their constituents what is happening in DC and why. The further the Fed moves from merely printing massive sums of money-something it should be able to do-to directing where that money goes, the more important is Congress' role.

The good news is that there is a solution. Congress can authorize what the Fed has done already and give it even broader authority to deal with this particular emergency. That authority could be either time limited (a few years), or it could be capped by reference to efforts to contain the fallout associated with Covid-19. As with the far more pressing fiscal stimulus package, the aim should be speed over perfection. Ensuring that the Treasury secretary continues to authorize any new facility could provide some ex ante check on the Fed's authority. Congress could also impose other mechanisms for promoting accountability without excessively limiting the Fed's flexibility through ex post mechanisms, such as delayed reporting and other requirements. 
An additional benefit of having Congress bless the Fed's action and to focus on ex post accountability is that it could stop any opportunistic denials of legal authority later in this crisis. Among the most fateful and controversial decisions the Fed madein discussions with Treasury-during the 2008 crisis was to allow Lehman Brothers to fail. Then-Federal Reserve Chairman Ben Bernanke defended the action as driven by a lack of legal authority. Others have vigorously contested this explanation. Nonetheless, the plausibility of that defense-which arises from the vagueness of the limitations on the Fed's authority as applied in times of crisis-has prevented a robust debate about whether that was a good policy decision. That mistake should not be repeated and very well could be if Congress does not intervene to clarify the Fed's authority to take the type of exceptional actions that this exceptional moment calls for.

Kathryn Judge is the Harvey J. Goldschmid Professor of Law at Columbia Law School.

This post was published on 27 March 2020. It first appeared on the Columbia Law School Blue Sky blog here. 


\title{
COVID-19 Crisis Requires Legislators to Adapt Insolvency Legislation
}

\author{
GERT-JAN BOON
}

The COVID-19 (corona) virus has reached pandemic status. It currently spreads over the world and is expected to infect a majority of all people within the next month(s), according to health experts. The medical urgency justifies the current extraordinary measures taken by many governments globally-measures that, at the same time, also have devastating effects on businesses and entrepreneurs as sectors slow down or are effectively closed down.

\section{Weathering the storm}

Strong appeals have been made to prevent bankruptcies caused by the COVID-19 crisis. The exogenous economic shock hits both financially reasonably healthy companies, which depend on a smooth inflow of liquidity, and companies with fundamentally solid business models. Many companies with a viable business model just a few weeks ago would now be forced to file and possibly suffer a piecemeal liquidation in the resulting insolvency proceedings. In the current, distressed market conditions there is a significant risk of sales at an under value.

Not surprisingly, many governments and institutions have announced economic measures to prevent an outbreak of businesses entering into liquidation proceedings. The European Commission published two communications dealing with the economic consequences of the COVID-19 crisis. In the first Communication on a coordinated economic approach the Commission announced several liquidity measures which complementing EU Member States may take that fall outside the scope of EU state aid rules. In the second Communication, the Commission announced a Temporary Framework for State Aid setting out and broadening the scope of state aid measures that fall within current EU state aid rules. Institutions such as the World Bank, IMF and ECB have also announced financial measures to strengthen economies.

\section{Prevent unnecessary bankruptcies}

The extraordinary economic situation raised by the COVID-19 outbreak requires legislators to undertake extraordinary measures. This extends also to insolvency legislation in order to prevent unnecessary bankruptcies. Insolvency legislation which 
is effective under normal market conditions may prove insufficient or ineffective in the current situation. Measures in these times should be effective without too many formalities, especially when courts and public authorities may not be fully available due to lockdown measures.

The Executive of the Conference on European Restructuring and Insolvency Law (CERIL) - an independent non-profit organisation of European lawyers and other restructuring and insolvency practitioners, law professors and (insolvency) judgesalso considers that existing insolvency legislation may not provide adequate responses to the situation in which many businesses currently find themselves. In a statement, the Executive calls upon EU and European national legislators to take immediate action to adapt insolvency legislation to prevent unnecessary bankruptcies.

\section{Adapting insolvency legislation}

CERIL suggests that two steps should be taken immediately by European national legislators. First, the duty to file for insolvency proceedings based on overindebtedness should be suspended. Such duties exist in several EU Member States, for instance Austria, Germany, Greece, Italy, Latvia, Poland and Spain. The current economic uncertainty hampers the effectiveness of this duty which is aimed at selecting non-viable businesses. In recent days, some countries have suspended (Germany) or extended (Austria) this duty. Second, in response to a (partial) shutdown of businesses for a number of weeks or months, urgent measures are required addressing the illiquidity of businesses.

In addition, the CERIL statement recommends that EU and national legislators consider further measures. In urgently adapting insolvency legislation, they should include measures to make available interim (crisis) finance, suspend the duty to file based on inability to pay, provide for 'hibernation' (going into winter sleep) of (small) businesses by means of a general moratorium or deferral of payments, and provide support for the livelihood of entrepreneurs and their employees.

The CERIL Executive Statement on COVID-19 and insolvency legislation is available here.

Gert-Jan Boon is Researcher and Lecturer in insolvency law at Leiden University.

This post was published on 27 March 2020. 


\title{
The Race to Fight COVID-19: On the Desirability of Regulatory Competition
}

\author{
HORST EIDENMÜLLER
}

Jurisdictions worldwide struggle with the COVID-19 pandemic. The two key policy goals are, first, to contain the spread of the virus to protect lives and, second, to minimize the damage to the economy to protect livelihoods. These policy goals are in potential conflict: drastic measures to contain the pandemic, such as a lockdown of private and commercial activities, will inflict huge costs on the economy. At the same time, it is also clear that reducing the spread of the virus does not only save lives. It has economic benefits as well by, for example, reducing healthcare costs and maintaining the size and health of the workforce and consumption levels.

Striking the right balance between pandemic control and containing the economic fallout is a delicate exercise, as is identifying the right measures that will (hopefully) achieve the specified regulatory goals. The Oxford COVID-19 Government Response Tracker (OxCGRT) records the unfolding government responses in a rigorous, consistent way across countries and across time. It also defines a 'Government Response Stringency Index', which ranges from 0 to 100, and plots it against the number of COVID-19 cases in a jurisdiction. The emerging picture is striking: some countries do nothing (0), some have brought public life almost to a standstill (100), and we see case numbers widely dispersed around a regression line, which is only very slightly upward sloping around a stringency of 60 .

Is this regulatory diversity a cause for concern? Some believe that the pandemic requires a (strictly) coordinated response. The President of the European Commission, Ursula von der Leyen, for example, demanded on 13 March 2020 that 'each Member State [of the European Union] needs to live up to its full responsibility. And the EU as a whole needs to be determined, coordinated and united'. Similarly, in a statement at the Extraordinary G20 Leaders' Summit on 26 March 2020, Chinese President Xi Jinping demanded 'a collective response for control and treatment at the international level.... Countries need to leverage and coordinate their macro policies'.

Yet, regulatory diversity and regulatory competition between jurisdictions in responding to the COVID-19 pandemic may be inevitable. We should not expect much of a planned collective response based on multilateral agreements. Rather, experimentation, diversity of approaches, and imitation will characterize the 
regulatory landscape, and for good reason. In a nutshell, against a backdrop of uncertainty about the optimal policy, and with differing priorities and contexts across jurisdictions, policy diversity and regulatory competition allow a rapid and productive learning process. This is a better 'treatment' for the pandemic than clumsy efforts at harmonising the policy responses across countries.

Various factors limit the degree of government coordination and collective action. First, beyond the nation-state, collective action depends on ad hoc consent, which is difficult to achieve and fragile. Even within nation-states, constitutional and political constraints may prevent federal governments from implementing specific policies. The European Union (EU) is a case in point. It has significant competencies with respect to the internal market. These are important during the crisis to maintain the free flow of goods, including medical supplies, across borders. But on health issues its formal role is all but nominal. Under Article 168 of the Treaty on the Functioning of the European Union, it is the EU countries that define and deliver their national health services and medical care. The EU is only empowered to complement national policies by means of its Health Strategy. Even within many of its Member States such as, for example, Germany and Italy, health issues are not for the federal government to decide, either. Rather, regional authorities or local governments are empowered to adopt and implement the policies and measures to contain the crisis. Local politicians want to be seen as energetically tackling the problem and addressing the concerns of the people in the jurisdiction in which they have been voted into office. When immediate action is required, they are likely to view engaging in difficult and timeconsuming coordination efforts as a second-order concern.

Second, states are hit by the pandemic at different points in time, and with different intensity. In Europe, for example, cases surged first in Italy. The virus then spread to neighbouring countries such as Switzerland, Austria and Germany, before affecting many other states, including the UK. In terms of the number of confirmed cases, for many weeks Germany has been lagging behind Italy by roughly one week, and the UK by two. It is unlikely that the same policies and measures should be implemented in jurisdictions regardless of when and how the virus affects them.

Third, countries differ-they have unique histories, cultures and traditions. People in different countries differ, too. Their preferences, for example with respect to the trade-off between health/safety and economic prosperity, their appetite or tolerance for risk, or their acceptance of curtailments of individual liberties, including their sensitivity to privacy issues, may significantly diverge. Different preferences will lead to different government responses to the COVID-19 pandemic. One can see this as an interesting new application of the 'Varieties of Capitalism' debate in economic/political theory (see Hall/Soskice (eds.), Varieties of Capitalism, 2001). The Oxford COVID-19 Government Response 
Tracker tracks this distinction, showing that coordinated-economy jurisdictions such as continental European ones have taken stricter measures than the 'liberal', marketfriendly ones, such as the US and the UK.

Consequently, it is unrealistic to expect much planned, multilateral coordination in the struggle to contain the spread of the virus and to mitigate the associated economic fallout. Even more importantly, though, this deficit in planned coordination may not be as great a cause for concern as it may appear. It may even be beneficial.

First, as explained above, even if it were theoretically possible to identify the optimal 'treatment' for the pandemic given the specific state of affairs in a particular jurisdiction at a particular point in time, such 'treatment' would always depend on the local preferences of the people in that jurisdiction. What is best-or tolerable-for the US is not necessarily best for France, South Korea or Japan, for example. There is no global optimum.

Second, and more importantly, identifying and implementing an optimal 'treatment' for the COVID-19 pandemic is illusory. Societies worldwide operate under a huge information deficit as regards how best to tackle the disease and its consequences for humans and economies. Scientists learn more and more about the virus, how it spreads, how it affects our health etc. Of course, we know that observing rules of basic hygiene and isolating carriers of the virus helps. However, we know very little about the effects of (marginally) different policies regarding, for example, forms of social distancing or quarantine on infection rates or economic losses. Even where we do not operate under a (huge) information deficit, implementing effective policies may be made difficult because of scarcity of resources. For example, mass testing is key, but testing kits are scarce and expensive.

Hence, it is not surprising that we see divergence in responses from various jurisdictions. As mentioned, the variance between countries in the Oxford COVID-19 Government Response Tracker in terms of adopted policies for each number of confirmed COVID-19 cases is significant. To put it differently: The data tells us little (if anything) on the (marginal) effectiveness of different policies on combating the pandemic. Similarly, we have little knowledge on the marginal effect of different specific policies on key economic factors such as GDP, frequency of business insolvencies or employment levels.

These are the kinds of conditions under which it appears reasonable to experiment and learn from the experiences that governments and policy-makers make in different countries. Some things work, others do not. Regulatory competition between jurisdictions has the potential to initiate a discovery process (Hayek) for the best or most efficient law. Different countries are adopting different measures, study 
the responses of other governments, and learn from the experience. The UK, for example, started out with relatively few restrictions on people's behaviour. However, after cases surged, and having the benefit of fresh data on the effects of more stringent measures by continental European states such as Austria or Germany, it adopted a more stringent line. The 'race' here is clearly to the top, in the sense of minimising the death toll. People in different jurisdictions want to 'win the war' against the virus with the tools their systems offer and by learning from others. Witness, for example, the interest and analysis surrounding the low death rates in Germany compared to the total number of cases: 'Germany's low coronavirus mortality rate intrigues experts', according to The Guardian.

The economic policies implemented to moderate the economic damage inflicted by the pandemic can be assessed similarly. Since long, Germany and the Netherlands, for example, had in place a social insurance system known as 'Kurzarbeitergeld' (wages for reduced working hours), whereby employees receive a significant portion of their wages if employers cut working hours in a crisis. 'Kurzarbeit: a German export most of Europe wants to buy' titled the Financial Times in an article ahead of the introduction of similar measures in other European countries, including in the UK.

I strongly doubt whether the same convergence could or would have been achieved based on multilateral negotiations between countries with the goal to agree on effective policy-measures. Experience tells that such coordination efforts frequently come to nothing-after precious time has passed and significant coordination costs have been sunk. If the efforts are successful, we might get a minimum consent, which might well distract from or even prevent the implementation of rapid and efficient policies on the local/nation-state level. This would reduce the level of experimentation, mutual learning and coordination through imitation (which is quite different from planned coordination).

An obvious counterargument to this analysis are potential externalities: is there not the risk that, if a large state such as the US 'gets it wrong', the negative consequences will be felt by people all over the world, similar to the financial and economic crisis in 2008-2009? The risk of externalities must be taken seriously. At the same time, the COVID-19 pandemic is different from the global financial and economic crisis in 2008-2009. One should distinguish between 'exporting' the virus (and the negative health and economic consequences that come with it) and directly 'exporting' negative financial and economic costs. Most borders are closed by now, so the risk that a country (re-)exports the virus to others appears to be relatively low. Reopening the borders can be calibrated by states-or supra-national bodies like the EU-to account for the specific regional risk of a (new) surge in cases. As far as economic and/or financial externalities are concerned, the current crisis is primarily a 
crisis of the real economy, not a crisis of 'systemically important' financial institutions or the financial system. The externalities imposed on the real economy are limited in scope. Global supply chains are still working reasonably well. Firms are in trouble primarily because the retail markets have been shut down in many countries. Hence, again, the risk of contagion appears to be relatively low-lower, at least, than in 20082009.

The stakes in the fight to contain the pandemic, minimise the death toll, and to mitigate the economic fallout could not be higher. Effective coordination of government policies by multilateral agreement appears to be a first-order concern. But such coordination is not a realistic prospect. Moreover, there are reasons to believe that the search for a worldwide 'optimal treatment' of the pandemic is not only illusory but distinctly harmful. Regulatory experiments on the level of nationstates or even local communities, rapid learning from the experience of others, and coordination through imitation may be the best way to win the war against the virus and to contain the associated economic fallout.

Horst Eidenmüller is Professor of Commercial Law at the University of Oxford.

I gratefully acknowledge the perceptive comments of my colleagues Luca Enriques and Thom Wetzer on earlier drafts of this post. The usual disclaimer applies.

This post was published on 31 March 2020. 